一原著一

隱匿情報検査の妥当性：記憶検出技法としての正確性の実験的検証

小川時洋，松田いづみ，常岡充子

\author{
科学警察研究所 \\ ₹277-0882 千葉県柏市柏の葉 6-3-1
}

\title{
Accuracy of Concealed Information Test as a Memory Detection Technique: A Laboratory Study
}

Tokihiro Ogawa, Izumi Matsuda and Michiko Tsuneoka

National Research Institute of Police Science

6-3-1 Kashiwanoha, Kashiwa, Chiba 277-0882, Japan

(Received 3 August 2012; accepted 14 November 2012)

\begin{abstract}
Currently, polygraph examinations in Japan use the concealed information test (CIT) to determine whether a suspect knows specific details of a crime. The present study examined the accuracy of the CIT as a memory detection technique in a mocktheft experiment. Participants were randomly assigned to either an encoding or nonencoding group. An expert polygrapher who was not informed of the group assignments, conducted a CIT that consisted of two questions. One inquired about a card number chosen by the participant, and the other regarded an item that had been stolen. Analyses focused on the second question. Roughly $20 \%$ of cases were judged inconclusive while sensitivity and specificity for the remaining cases were $86 \%$ and 95 $\%$, respectively. Analysis was repeated using modified Lykken scoring, and rates of inconclusive cases, sensitivity, and specificity by this method were $25 \%, 83 \%$, and $91 \%$, respectively.
\end{abstract}

Key words: Concealed information test, Accuracy, Physiological activity

\footnotetext{
緒 言

現在の日本の犯罪捜査で実施されているポリグラ フ検査は，事件事実に関する被検査者の認識の有無 を調べることを目的としている，その方法は，有罪 知識検査もしくは隠匿情報検査（Concealed Information Test, CIT) と呼ばれる1,2).CITでは，事件 内容を知っている者であれば事件事実として認識す ると考えられる内容と，それと類似するが事件とは
}

無関係で，事件事実として認識しないと考えられる 内容を持つ複数の質問を組み合わせた質問表を作成 する. 質問表の内容は, 事件内容を知らない者に は，何れが事件事実であるかが分からないように構 成する. 例えば，凶器にベルトが使用されたことが 判明している絞殺事件で, 被検査者がこの凶器を知 っているかどうかを検査する場合, 質問表にはベル 卜 (裁決項目) の他に, 同じく絞殺の凶器となり得 るネクタイやスカーフ, 電気コードなど (非裁決項 
目）を含める。検査では，これらの質問項目を被検 查者に提示し, その間の被検查者の呼吸運動, 皮膚 電気活動, 心臓血管系活動などの生理的变化を記録 する.もし, 裁決項目提示時に他の質問項目とは異 なる生理的变化が見られた場合，その被検査者は凶 器がベルトであることを知っていると推定する。一 方, 裁決質問と非裁決質問とで生理的变化に差異が 認められない場合, 被検査者が凶器はべルトである ことを知らないと推定する（以上は原則であり文献 3 も参照のこと). このようにCIT とは, 特定の質 問に対して并別的な生理的変化が生起するかどうか を手がかりに，質問内容が指し示す事件事実を被検 查者が知っているかどうかを調べる心理検査の一種 である。な抏，CITには裁決質問法と探索質問法 の下位分類がある. 前記の被検査者が “ベルト”が 凶器であることを知っているかどうかを調べる手続 きは, 裁決質問法に分類される. 一方, 探索質問法 では “ベルト”のように特定の項目に限定せず，被 検査者が質問表中の何れかの質問項目を事件内容と してとらえているかどうかを調べる.しかし, 探索 質問法も, 特定の質問項目に対して他と異なる生理 的変化が見られるかどうかを調べる点は裁決質問法 と共通する。

心理検査としての CIT の正確性は，この手法の 応用的有用性を規定する重要な要因の一つである。 現在の日本の警察が用いているCIT は, 質問表単 位で記憶の有無を検査しているため, 本研究では正 確性を質問表単位での検査結果と実際の記憶の有無 との対応の程度と定義する。この定義は, CITを 含めたポリグラフ検査の正確性に関する海外・国内 の先行研究とは異なる. 例えば, 奈良県警で実施さ れた実務検査の分析例 (4) では, 複数の質問表の結果 をまとめた総合判定の結果と, 被検査者がその後の 捜査で犯人あるいは無実と判明したかどうかとの関 連を扱っている。 また, 海外で公刊された実務場 面5,6) や実験場面1,2) に抢けるCIT の正確性抢よびそ のメタ分析 ${ }^{7-9)}$ 研究でも, 個々の質問表の内容に関 する記憶の有無を基準変数とした例は少ない（文献 10 も参照).

一方, 本研究と同様に, 個々の質問表単位で CITの正確性を分析した事例も存在する. 横井
$ら^{11)}$ は, 実務で行われた検査のうち, その後の捜査 の結果から記憶と検查結果との照合ができた217事 例1137質問表を対象に, CITの正確性を分析し た。 その結果，質問対象となった事象を記憶してい た場合にそれを正しく判断できた割合（感度）は $87.8 \%$, 記憶していない場合にそれを正しく判断で きた割合 (特異度) は，64.8\%であった 1 しかし， 彼らの分析では生理的変化の差異の有無が判定しが たく, 記憶の有無は不明と結論された事例を, 記憶 無しと結論されたものして処理している. そのた め, 実際に記憶無しと結論した事例に限定した場合 の特異度が不明である. また, 判断の根拠となった 生理的変化のデータが示されておらず，どの程度の 生理的变化の差異の下で上記の感度 ·特異度が得ら れたのかが分からない。さらに現在の実務検査で は, 呼吸運動, 皮膚電気活動に加えて, 心拍率 (Heart Rate, HR) や規準化脈波容積 (Normalized Pulse Volume, NPV) 12)を計測しているが，当時の 実務検査ではこれらの心臓血管系の生理指標の使用 は一般的ではなかった. 以上の理由から, 横井らの 分析結果が現在の CIT の正確性を示すかどうかは 不明である。また，新たに導入された生理指標につ いては, 実験・実務共に研究・分析事例は幾つか存 在するが3,12), 検査の正確性に焦点を当てて行われ たものはない.

結局, 現在の日本の CIT の正確性については知 見が十分ではない。本研究は, CIT の正確性を実 験場面において検証することを目的とした．実験場 面は, 実務検査と異なり被検査者である実験参加者 の記憶の確実な確認が可能であるという利点を持 つ. 実務検査で正確性を検証する場合, 対照するべ き被検査者の実際の記憶の有無の確認に, しばしば 困難が伴う13)。 その点で実験場面での検証は意義を 有する.ささに, 本研究では生理的変化のデータに ついても分析を行った. 判定の根拠となる生理的変 化が明らかであれば，将来の実務データの分析結果 との比較も可能となる.

実験では，実験参加者をランダムに記銘群・非記 銘群に分け 2 , 記銘群は室内に隠された指輪を模擬

1原文では, 感度・特異度ではなく, Hit 率, Correct Rejection 率のような信号検出理論の用語を用いている. 
的に窃取する模擬窃盗を実行した。その後, 指輪を 裁決項目とするCITを実施した。その際，実験者 は実験参加者が記銘群・非記銘群いずれの条件に属 するのかを知らされない状況で検査を行い，実験参 加者が盗まれた品物が指輪であることを知っている かどうかを判定した，また，実務検査と同様，盗品 に関するCITを実施する前には，実験参加者の生 理状態の確認とCITの手続きの理解を促す目的 で, 模擬検查を実施した。模擬検査では, 実験参加 者に 5 枚の数字カードの中から 1 枚を選ばせ, カー ドの数字を質問項目に用いた検查を行った。したが って模擬検査は，被検査者が必ず質問表のいずれか の項目を答えとして認識する特殊な探索質問法と見 なせる. 得られた生理データの評価・判定は, 実務 と同様, 実験者が目視によって行った。ささらに本研 究では, Lykken Scoringによる判定も行った。

Lykken Scoring は，我が国では実務・研究ともに 使用例は見あたらない。しかし, 海外のCIT 研究 ではよく使われる客観的判定法であることか $ら^{1,5,14)}$, 本研究では訓練を積んだ専門家による判 断と比較する一つの基準として用いた.

\section{方 法}

実験参加者 167名（男88名, 女79名, 18-59歳, 平 均37.1歳, SD 11.6歳）が実験に参加した。実験参 加者は, 特定の年代に人数が偏らない形で募集し,

くじによって記銘群 $(n=86)$ と非記銘群 $(n=81)$ に無作為に振り分けた ${ }^{3}$.

実験者 ポリグラフ検査研究抢よび実務検査に従事 している36名が，実験者として生理活動の計測およ び判定を行った．実験者には，判定作業が終了する まで実験参加者が属する群を伝えられなかった。

刺激 模擬検査には， 3 から 7 までの 5 つの数字を 質問項目として用いた。模擬穷盗課題の窃取品につ いて尋ねる質問表の質問項目には，裁決項目の指輪 のほか, ネックレス, イヤリング, 腕時計, ブロー チを用いた。

\footnotetext{
2本研究のような実験では, 犯人群・無実群という名称が一般 的である.しかし，記憶検査としての CIT の性格を明確にする ため, 本研究ではこの名称を用いた.

3両群の人数の違いは, 役割を振り分けるくじの作成上の過程 で偶然に生じたものである.
}

生理指標の測定 デジタルポリグラフ装置（PTH347 もしくは PTH-347MkII，ティアック）を用い て, 呼吸運動, 皮膚電気活動, HR, NPV を測定·

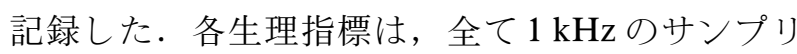
ングレートでデジタル変換してパーソナルコンピ ュータのハードディスクに記録した。呼吸運動は, 実験参加者のみぞ括ち付近に呼吸ピックアップ （PP-C011，ティアック）を装着し, 得られた信号 を直流増幅し， $5 \mathrm{~Hz}$ のハイカット・フィルターを 通して記録した. 皮膚電気活動は, 実験参加者の非 利き手の第 $2 \cdot 3$ 指末節にディスポ電極（PPS$\mathrm{EDA}$ ，ティアック）を装着し，0.5 V の定電圧回路 を用いて $5 \mathrm{~Hz}$ のハイカット・フィルターを通した 信号から皮膚伝導度水準（Skin Conductance Level, SCL) と皮膚伝導度反応（Skin Conductance Response, SCR）を計測した. SCL は直流増幅した 信号から記録した. SCR は, 時定数 $5 \mathrm{~s}$ で増幅した 信号から求めた. HR 計測のため, 心電図を両足首 と右手首にディスポ電極を装着し, 時定数 $0.1 \mathrm{~s}, 30$ $\mathrm{Hz}$ のハイカット・フィルターを通して増幅した。 各拍動の瞬時 HRを, デジタル記録された心電図 の $\mathrm{R}-\mathrm{R}$ 間隔時間に基づいてオンラインで算出し た. NPVは, 透過型指尖容積脈波のプローブを非 利き手第 4 指に装着して導出した波形信号を直流成 分々交流成分の 2 系統に分け, 交流成分は時定数 $0.3 \mathrm{~s}$ で増幅した. 各拍動の交流成分の脈波の振幅 を, 対応する同一心周期の直流成分の平均值で除し たものを，1拍ごとにオンラインで算出した.

手続き 実験は, 実験参加者ごとに個別に実施し た。実験参加者には, 実験での役割を示すくじを封 入した封筒を事前に手渡しており, 実験室に来室時 にそれを持参した。最初に, 実験補助者が実験の概 要について説明し, 実験参加への同意を書面で確認 した. 続いて, 実験参加者には, 実験補助者の退室 後にくじの内容を確認し,「犯人役」と記されてい たのであれば，部屋に隠された封筒を探しだし，中 身を確認した上で封筒を中身ごと隠し持っておくよ うに教示し，その後で実施される検査で自分の役割 が分からないように振る舞うことを求めた．封筒の 中身については述べなかった。一方, 実験参加者が 「無実役」と書かれたくじを引いたのであれば，何 
もせずに部屋で待機するよう教示した. その後, 実 験補助者が退室し, 実験参加者はくじの確認および 記銘群であれば模擬窃盗を行った．数分の時間をお いて実験補助者が再度入室し, 実験参加者を実験者 のいる検査室に案内した.

検査室では, 実験参加者が選んだ数字を尋ねる模 擬検査と, 実験室に隠された封筒の中身について尋 ねる本検査の 2 質問表で構成される CIT を実施し た. 実験者が各種電極などを実験参加者に装着した 後, 数字が記された 5 枚のカードから, 任意に 1 枚 を選ばせ，その数字を実験者に分からないように紙 に記録させた，続いて，実験参加者に選んだ数字に ついて質問をするので，全ての質問に“いいえ”と 口頭で回答すること，自分が選んだ数字を隠すつも りで検査を受けるように教示した後, 実験参加者の 生理状態の確認および検査手続きへの理解を促すた めに模擬検查を実施した。模擬検查の終了後, 実験 者は実験参加者が選んだ数字を確認した. 模擬検査 に続いて，封筒に入っているものについて，指輪を 裁決項目とする本検査を実施した。 ぞちらの CIT も， 5 項目を一通り提示することをもって 1 セット とし，項目の順番を入れ替えながら5セット実施し た. 5 セットを通じて, 各質問項目は第 1 項目から 第 5 項目の各系列内位置に一度ずつ提示された. 質 問は口頭で行ったほか, 実験参加者の前方に設置し たモニターにも文字で発問にあわせて $3 \mathrm{~s}$ 間提示さ れた。実験参加者の返答から次の質問まで, 最低 25 $\mathrm{s}$ をうけた。検查室の平均室温は $25.5^{\circ} \mathrm{C}(S D=$ $\left.0.94^{\circ} \mathrm{C}\right)$ であった. CIT の終了後, 実験補助者が入 室して実験参加者を別室に案内し, 実際の役割と, 記銘群であれば盗んだ封筒を所持しているかどうか などを確認した。

判定 実験者は, 各実験参加者の模擬検査と本検査 のデータに基づき, 実験参加者が封筒の中身が指輪 であることについて, “知っている”か“知らない” か, あるいは “不明 (判定困難)” であるかを判定 した. 模擬検査の結果は, 実験参加者の各生理指標 に抢ける反応性を把握する一助として用いられた。

生理指標の分析 SCR は, 質問提示後から $5 \mathrm{~s}$ 以内 に生起した変化の最大振幅として計測した。呼吸運 動は, 返答後 $10 \mathrm{~s}$ 間を解析対象とし, $20 \mathrm{~Hz}$ にダウ
ンサンプリングして $4 \mathrm{~Hz}$ の高域遮断フィルタをか けた。足立・鈴木等 ${ }^{15,16)}$ に従い，この区間の呼吸波 形に抢ける振幅方向の絶対的変化量の合計值を解析 時間 $(10 \mathrm{~s})$ で除した呼吸速度と, 吸息相・呼息相 の位相別の単位時間あたりの軌跡長である吸息速 度 ·呼息速度を求めた. また, 解析時間中に生じた 呼吸について, 呼吸波形のピークとボトムの差分で ある振幅と, 波形の頂点間の間隔を 1 分あたりのサ イクル数に変換した呼吸率を計測した. 質問提示後 $15 \mathrm{~s}$ 間の平均 $\mathrm{HR}$ 加質問提示前 3 拍の $\mathrm{HR}$ を減 算したものを $\mathrm{HR}$ 変化とした. $\mathrm{HR}$ 平均抢よび $\mathrm{NPV}$ 平均として, 質問提示後 $6 \mathrm{~s}$ から $16 \mathrm{~s}$ までの 10 $\mathrm{s}$ 間の平均值を求めた. 以上の各測度では, 各実験 参加者につき 25 個のデータ（5 項目 $\times 5$ セット）が 得られ (以上は, 文献15,16に準拠した), 測度毎, 実験参加者毎に25個のデータの平均・標準偏差を用 いて各データの標準化を行った。この標準化值につ いて裁決項目の平均を求め, 0 を検定值とする 1 標 本の $t$ 検定を群別に行った. 検定の結果, 0 との差 異が有意であれば，当該測度において裁決項目と非 裁決項目に差異が見られたことを示す4. なた，群 間比較のため, 対応のない $t$ 検定とCohen's $d$ によ る効果量 ${ }^{17)}$ を求めた。さらに, SCL, HR, NPV は, セット内の全データポイントの平均と標準偏差 を用いてセット毎に標準化した。裁決・非裁決項目 毎に，質問提示後 $20 \mathrm{~s}$ 間を各 $5 \mathrm{~s}$ の 4 ブロックに分 けて平均值を求めた。 これらの測度については, 群 （記銘·非記銘）を個人間要因, 項目（裁決·非裁 決）とブロック（1-4）を個人内要因とする 3 要因 の分散分析を行った。自由度の調整には, Greenhouse-Geisser の $\varepsilon$ を用いた。

続いて，裁決・非裁決項目間の差異の分布を群間 で比較するため, 受信者動作特性曲線（Receiver Operating Characteristic curve: ROC 曲線) を測度 別に算出し，その曲線下の面積と $95 \%$ 信頼区間を求 めた. SCL は分析ブロックごとに裁決項目から非 裁決項目の平均を減算した差分值を，HR, NPV は 非裁決項目から裁決項目を減算した差分值を求め

\footnotetext{
4標準化の手続きから, 裁決項目の值が決まると非裁決項目の 平均も決をるため, データの独立性の観点からこれらの測度で は裁決項目のみを分析対象とした。
} 
た・その他の測度では，裁決項目の平均值を用い た。

Lykken Scoring による判定 実験者による評価の 他に Lykken Scoringによる判定成績も求めた。群 間の差異の効果量が.70以上となった測度につい て，セットごとに皮膚伝導度（Skin conductance， SC) は大きい順に，その他の指標では小さい順に， 各項目の反応量の順位づけを行った。次に裁決項目 が 1 位の場合には 2 点， 2 位の場合には 1 点を付与 し，その得点をセット間で合計した1,5,14). 呼吸・ $\mathrm{SC} \cdot \mathrm{HR} \cdot \mathrm{NPV}$ の各指標に複数の測度があるが，参 加者ごとに最大得点を示した測度をその指標の得点 とした，指標毎の得点を，対応のない $t$ 検定を用い て群間で比較した。ささらに，指標毎に弁別的反応あ り，弁別的反応なしとする基準值を，探索的に求め た。 また，指標が複数にわたるため，指標を統合す るためのルールも探索的に検討して設定した．基準 の設定に際しては，特異度を90\%以上で，感度がで きるだけ高くなり，かつ不明事例ができるだけ少な
くなる基準を探った。

\section{結 果}

167名の実験参加者のうち，記銘群で封筒を見つ けられなかった者や非記銘群で封筒を触った者など 実験手続きに問題があった者(男 1 名，女 3 名)や, 居眠りや体動など計測に問題があった者（男 6 名， 女 5 名）のデータを分析から除外し，152名（記銘 群80名，非記銘群72名）を有効データとした。

実験者による判定結果

Table 1 に判定結果を示す。裁決項目を知ってい るか知らないかについて明確な結論を出せた事例は 121名（80\%）であり，不明と判定された事例が， 記銘群で14名，非記銘群で17名あった。不明事例を 除外すると ${ }^{6,18)}$ ，記銘群で裁決項目を知っていると 判定された事例（感度）は，66名中57名（86\%）で あった。同様に非記銘群で裁決項目を知らないと判 定された事例（特異度）は，55名中52名（95\%）で あった. 群と判定結果の連関係数（ $\phi$ 係数）は.81

Table 1 Obtained frequencies of the CIT decision by the experts and modified Lykken Scoring.

\begin{tabular}{cccccc}
\hline Judge & Group & Recognized & Not Recognized & Inconclusive & Total \\
\hline Experts' & Encode & 57 & 9 & 14 & 80 \\
Evaluation & No Encode & 3 & 52 & 17 & 72 \\
Modified Lykken & Encode & 50 & 10 & 20 & 80 \\
Scoring & No Encode & 5 & 49 & 18 & 72 \\
\hline
\end{tabular}

Table 2 Averages of physiolgoical responses to the critical item ${ }^{\text {a) }}$.

\begin{tabular}{|c|c|c|c|c|c|c|c|c|}
\hline \multirow{2}{*}{ Measures } & \multicolumn{4}{|c|}{ Encode } & \multicolumn{4}{|c|}{ No Encode } \\
\hline & $n$ & $M^{\mathrm{b})}$ & $S D$ & $t^{\mathrm{c})}$ & $n$ & $M^{\mathrm{b})}$ & $S D$ & $t^{\mathrm{c})}$ \\
\hline Respiratory speed & 66 & -.42 & 0.5 & $6.98^{*}$ & 69 & -.02 & .31 & .46 \\
\hline Inspiratory speed & 66 & -.36 & 0.5 & $5.88^{*}$ & 69 & .00 & .30 & .08 \\
\hline Expiratory speed & 66 & -.44 & 0.5 & $7.27^{*}$ & 69 & -.03 & .34 & .85 \\
\hline Respiratory amplitude & 66 & -.23 & 0.4 & $4.68^{*}$ & 69 & -.04 & .32 & .92 \\
\hline Repiartory rate & 66 & -.30 & 0.5 & $4.75^{*}$ & 69 & .01 & .37 & .29 \\
\hline SCR & 70 & .57 & 0.5 & $9.92^{*}$ & 53 & -.09 & .34 & $1.90^{\dagger}$ \\
\hline HR change & 76 & -.44 & 0.5 & $7.98^{*}$ & 69 & .04 & .44 & .70 \\
\hline Mean HR & 76 & -.58 & 0.5 & $10.18^{*}$ & 69 & .01 & .36 & .17 \\
\hline Mean NPV & 74 & -.28 & 0.4 & $6.32^{*}$ & 66 & -.02 & .30 & .49 \\
\hline
\end{tabular}

a) Abbreviations mean as follows: SCR, skin conductance response; HR, heart rate; NPV, nomalized pulse volume.

b) All data indicates $z$-transformed values.

c) Symbols indicate statistical significance levels of $t$-tests: ${ }^{\dagger} p<.10,{ }^{*} p<.01$ 
$(p<.01)$ であった.

\section{生理指標}

有効事例152名のうち, 皮膚電気活動の分析で は, 機器の校正不良や本検查時に質問に対して SCR がほとんど生起しなかった（10回以下）など の事由で29名を除外した。計測上の事由から, 呼 吸・HR·NPVそれぞれについて, 17名, 7 名, 12 名を除外した。

Table 2 には, 呼吸関係の測度, SCR, HR 変 化, $\mathrm{HR}$ 平均, $\mathrm{NPV}$ 平均の平均を示す. 記銘群で は, 非裁決項目提示時に比べて裁決項目提示時には 呼吸活動・HR·NPV が有意に低く, SCR が有意に 大きかった。一方，非記銘群では裁決項目提示時の SCR が低い傾向が見られた他は, 裁決・非裁決間 の差異は見られなかった。これらの測度について, 対応のない $t$ 検定を行った結果抢よび効果量は Table 3 の右に掲出した. 全ての測度において群間の 差異が有意であった。 また, 群間の差異の効果量は $\mathrm{SCR}$ で最も大きかった $(d=1.56)$. その他, 呼吸 速度や HR 関係の測度でも.80以上の大きな効果 量 ${ }^{17)}$ が見られた。

Fig. 1 には, 質問提示後 $20 \mathrm{~s}$ 間の $\mathrm{SCL} \cdot \mathrm{HR} \cdot \mathrm{NPV}$ を示す. 記銘群では, 非裁決項目提示時に比べ, 裁 決項目提示時の SCL は高く, HR と NPV は低かっ た. 非記銘群では, 裁決・非裁決項目間の差異は小 さかった. 分散分析の結果, 全ての指標で役割 $\times$ 項 目×ブロックの交互作用が有意であった $(\mathrm{SCL}, F$ $(3,363)=18.92, \varepsilon=.60, p<.01, \eta_{\mathrm{p}}{ }^{2}=.14 ; \mathrm{HR}, F$ $(3,429)=16.35, \varepsilon=.82, p<.01, \eta_{\mathrm{p}}{ }^{2}=.10 ; \mathrm{NPV}, F$ $\left.(3,414)=5.71, \varepsilon=.63, p<.01, \eta_{\mathrm{p}}{ }^{2}=.04\right)$. 下位検定 の結果, 記銘群に打ける裁決 ·非裁決間の差異は, SCL ではブロック 2-4において $(F \mathrm{~S}(1,552)>$ $30.77, p \mathrm{~s}<.01), \mathrm{HR}$ と NPVは全てのブロックに おいて $\left(\mathrm{HR}, F_{\mathrm{S}}(1,572)>23.17 p \mathrm{~s}<.01 ; \mathrm{NPV}, F \mathrm{~S}\right.$ $(1,552)>8.35 \mathrm{ps}<.01)$ それぞれ有意であった. 非 記銘群では, 裁決・非裁決間の差異は全ての指標 · ブロックで有意ではなかった $(p \mathrm{~s}>.25)$. 裁決・非 裁決間の差異に関する群間の違いの効果量は, Table 3 に掲出した。第 2 ブロック以降の HR, NPV の第 2 ブロックで, 大きな効果量の差異が見られ, SCL の第 2 ブロック以降およびNPV の第 3 ブロッ
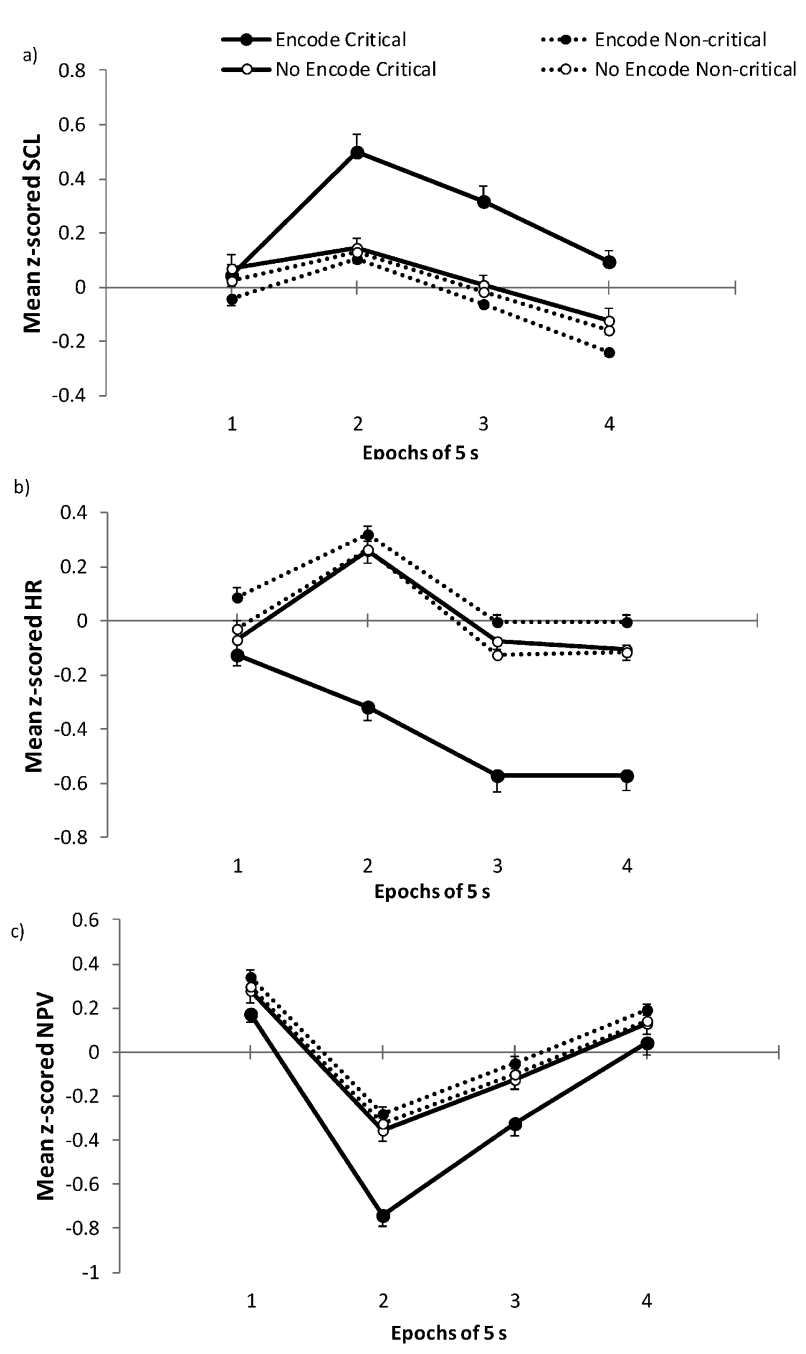

Fig. 1 Averages of (a) skin conductance level (SCL), (b) heart rate (HR), and (c) normalized pulse volume (NPV) for each item and group.

Note: Bars indicate standard errors (SEs).

クでは差異の効果量は中程度であった.

ROC曲線による分析結果を Table 3 に示す. ROC 曲線による分析では, SCLの第1 ブロックと NPV の第 1.4 ブロックを除く全ての測度で有意な 識別が見られ, 面積は.64 (呼吸振幅) から.87 （SCR）の範囲となった.

\section{修正 Lykken Scoring による判定}

Table 4には, Lykken Scoring の得点分布を群別 に示す。全ての指標において, 平均值は認識めり群 の方が認識なし群よりも高く, 検定の結果でも群間 の差異が有意であった（呼吸 $: t(133)=6.79, p$ 
Table 3 ROC analyses and paried $t$-tests between groups.

\begin{tabular}{|c|c|c|c|c|c|c|}
\hline \multirow{2}{*}{ Measures $^{\text {a) }}$} & \multirow{2}{*}{ Area } & \multicolumn{2}{|c|}{$95 \%$ Confidence interval } & \multicolumn{3}{|c|}{ Independent sample $t$-test } \\
\hline & & Lower & Upper & $t^{\mathrm{b})}$ & $d f$ & $d$ \\
\hline Respiratory speed & .76 & .68 & .84 & $5.72^{*}$ & 133 & .99 \\
\hline Inspiratory speed & .74 & .65 & .83 & $5.07^{*}$ & 133 & .88 \\
\hline Expiratory speed & .74 & .66 & .83 & $5.58^{*}$ & 133 & .97 \\
\hline Respiratory amplitude & .64 & .55 & .73 & $3.19^{*}$ & 133 & .55 \\
\hline Repiartory rate & .68 & .59 & .77 & $4.10^{*}$ & 133 & .71 \\
\hline SCR & .87 & .81 & .93 & $8.52 *$ & 121 & 1.56 \\
\hline SCL Block 1 & .51 & .41 & .61 & .59 & 121 & .11 \\
\hline SCL Block 2 & .71 & .62 & .80 & $4.14^{*}$ & 121 & .76 \\
\hline SCL Block 3 & .72 & .63 & .81 & $4.32 *$ & 121 & .79 \\
\hline SCL Block 4 & .71 & .62 & .80 & $3.88^{*}$ & 121 & .71 \\
\hline HR change & .77 & .69 & .85 & $6.22^{*}$ & 143 & 1.04 \\
\hline Mean HR & .83 & .77 & .90 & $8.09^{*}$ & 143 & 1.36 \\
\hline HR Block 1 & .66 & .57 & .75 & $3.04 *$ & 143 & .51 \\
\hline HR Block 2 & .85 & .79 & .91 & $8.60^{*}$ & 143 & 1.44 \\
\hline HR Block 3 & .80 & .72 & .87 & $7.03^{*}$ & 143 & 1.18 \\
\hline HR Block 4 & .81 & .74 & .88 & $7.59^{*}$ & 143 & 1.27 \\
\hline Mean NPV & .70 & .62 & .79 & $4.50^{*}$ & 138 & .77 \\
\hline NPV Block 1 & .59 & .49 & .68 & $1.74^{\dagger}$ & 138 & .30 \\
\hline NPV Block 2 & .75 & .66 & .83 & $4.90^{*}$ & 138 & .84 \\
\hline NPV Block 3 & .67 & .58 & .76 & $3.42^{*}$ & 138 & .58 \\
\hline NPV Block 4 & .59 & .50 & .69 & $1.82^{\dagger}$ & 138 & .31 \\
\hline
\end{tabular}

a) Abbreviations mean as follows: SCR, skin conductance response; SCL, skin conductance level; HR, heart rate; NPV, nomalized pulse volume.

b) Symbols indicate statistical significance levels of $t$-tests: ${ }^{\dagger} p<.10,{ }^{*} p<.01$

Table 4 Distributions of Lykken's score ${ }^{\mathrm{a})}$.

\begin{tabular}{|c|c|c|c|c|c|c|c|c|}
\hline \multirow{2}{*}{ Score } & \multicolumn{2}{|c|}{ Respiration } & \multicolumn{2}{|c|}{$\mathrm{SC}$} & \multicolumn{2}{|c|}{ HR } & \multicolumn{2}{|c|}{ NPV } \\
\hline & Encode & No Encode & Encode & No Encode & Encode & No Encode & Encode & No Encode \\
\hline 0 & $0(0 \%)$ & $1(1 \%)$ & $0(0 \%)$ & $0(0 \%)$ & $0(0 \%)$ & $0(0 \%)$ & $3(4 \%)$ & $1(2 \%)$ \\
\hline 1 & $0(0 \%)$ & $3(4 \%)$ & $1 \%)$ & $2(4 \%)$ & $0 \%)$ & $1 \%)$ & $3(4 \%)$ & $9(14 \%)$ \\
\hline 2 & $2(3 \%)$ & $10(14 \%)$ & $3(4 \%)$ & $7(13 \%)$ & $0 \%)$ & $4(6 \%)$ & $6(8 \%)$ & $11(17 \%)$ \\
\hline 3 & $6(9 \%)$ & $19(28 \%)$ & $7(10 \%)$ & $20(38 \%)$ & $3 \%)$ & $12(17 \%)$ & $8(11 \%)$ & $13(20 \%)$ \\
\hline 4 & $15(23 \%)$ & $15(22 \%)$ & $11(16 \%)$ & $10(19 \%)$ & $7(9 \%)$ & $19(28 \%)$ & $15(20 \%)$ & $20(30 \%)$ \\
\hline 5 & $9(14 \%)$ & $11(16 \%)$ & $11(16 \%)$ & $10(19 \%)$ & $10(13 \%)$ & $12(17 \%)$ & $10(14 \%)$ & $8(12 \%)$ \\
\hline 6 & $3(5 \%)$ & $5(7 \%)$ & $12(17 \%)$ & $1(2 \%)$ & $10(13 \%)$ & $14(20 \%)$ & $11(15 \%)$ & $1(2 \%)$ \\
\hline 7 & $6(9 \%)$ & $4(6 \%)$ & $8(11 \%)$ & $4 \%)$ & $14(18 \%)$ & $4(6 \%)$ & $10(14 \%)$ & $3 \%)$ \\
\hline 8 & $11(17 \%)$ & $1(1 \%)$ & $6(9 \%)$ & $2 \%)$ & $10(13 \%)$ & $4 \%)$ & $6(8 \%)$ & $0 \%)$ \\
\hline 9 & $7(11 \%)$ & $0(0 \%)$ & $7(10 \%)$ & $0 \%)$ & $13(17 \%)$ & $0 \%)$ & $0(0 \%)$ & $2 \%)$ \\
\hline 10 & $7(11 \%)$ & $0(0 \%)$ & $4(6 \%)$ & $0(0 \%)$ & $10(13 \%)$ & $0(0 \%)$ & $2(3 \%)$ & $0 \%)$ \\
\hline Total & $66(100 \%)$ & $69(100 \%)$ & $70(100 \%)$ & $53(100 \%)$ & $76(100 \%)$ & $69(100 \%)$ & $74(100 \%)$ & $66(100 \%)$ \\
\hline$M$ & 6.18 & 3.78 & 5.80 & 3.66 & 7.09 & 4.59 & 4.77 & 3.32 \\
\hline$S D$ & 2.41 & 1.64 & 2.24 & 1.44 & 1.99 & 1.56 & 2.27 & 1.66 \\
\hline
\end{tabular}

a) Abbreviations mean as follows: SC, skin conductance; HR, heart rate; NPV, nomalized pulse volume. 
$<.01, d=1.18$; SC: $t(121)=6.09, p<.01, d=1.11 ;$ HR: $t(143)=8.37, p<.01, d=1.40$; NPV: $t(138)=$ $4.28, p<.01, d=0.73)$. なお , 非記銘群の Lykken Scoring の期待值は 3 であるが， Table 4 の值はこ れより大きい。これは, 指標毎に複数存在する測度 の中で最大值を選ぶという手続きに由来すると考え られる. 測度別にみた場合, SCRの得点の平均值 が 3 より低くなった $(M=2.28, S D=1.71, t(52)=$ $3.05, p<.01)$ 他は, 非記銘群で平均值が有意に 3 と異なる測度は見あたらなかった。この分布を参考 に，呼吸では 8 点以上であれば弁別的反応あり， 4 点以下は并別的反応なし， 5 点から 7 点までを不明 瞭とした。他の指標についても同様に, SC と HR は 7 点以上，NPVは 6 点以上を弁別的反応ありと し, 并別的反応なしの基準は, 呼吸と SC は 3 点以 下, HR と NPVは 4 点以下とし, 残りは不明瞭と した。 また，複数の指標を統合については，4 指標 のうち弁別的反応ありとなった指標が 2 指標以上,

もしくは 1 指標で残り 3 指標全てが不明瞭の場合 に, 裁決項目を知っていると判定した. 残るケース で, 弁別的反応なしの指標が 2 つ以上あれば, 裁決 項目を知らないと判定し, 残りは全て不明と判定し た. 以上の基準による判定結果を, Table 1 の下段 に示す。不明と判定されたケースは, 記銘群で20 例, 非記銘群で18例であり, 結論が出せたケースは 114例 (75\%) であった。感度は60名中50名 (83\%), 特異度は, 54名中49名（91\%）であった. 群と判定 結果の $\phi$ 係数は.74 $(p<.01)$ であった.

\section{考 察}

本研究は, CIT の正確性を実験場面において評 価することを目的とした。生理指標の結果を見る 々, 先行研究3,12) と同じく, 記銘群では裁決項目提 示時には, 非裁決項目提示時に比べて SC が大き く, 呼吸・HR·NPV は低かった。非記銘群では, 裁決・非裁決項目間に有意な差異は見られなかっ た.さらに, SCR における記銘群と非記銘群の差 異の効果量は, 先行研究のメタ分析7)で報告されて いる効果量の平均 $(d=1.55)$ とほぼ同じであった.

これらの生理的変化に基づく実験者による判定結 果は, 感度が $86 \%$, 特異度が $95 \%$ であった. CIT
の正確性に関する先行研究では, 一般に感度よりも 特異度の值が高くなる傾向が基準変数の違いを越え てみとめられるが5,6,8), 本研究の結果もそれに合致 する。また，裁決項目を記憶しているか否かについ て明確な結論が出せなかった事例が $20 \%$ 存在した。 これらの結果は, 複数名の実験者による判定結果を 集計したものであることから，特定の実験者による バイアスではない。 また, 修正 Lykken Scoringに よる評価でも.83の感度と.91の特異度が得られ た。以上から本結果は，日本で用いられている CIT というパラダイムの正確性に関する一つの目 安と見なして良いと思われる.

現在の CIT に関する心理生理学的研究は, 実験 室場面の研究が多く, しばしば現実場面とのずれ， すなわち生態学的妥当性が議論される ${ }^{19)}$.この観点 からは, 本研究のような実験場面で得られた正確性 は実務検査と異なるのではないか，という疑問もあ り得る。しかし, 現時点では裁決項目と非裁決項目 の生理的变化の差異の現れ方が，実験場面と実務場 面で全く異なるとする知見は見あたらない3)。した がって, 単に実験場面であることをもって, 本研究 の結果の妥当性を論じることは適当ではない20)。も し, 実務検査においても本研究と同程度の生理的変 化の差異が見られるのであれば，本研究の結果は実 務場面にも一般化できると考えられる．実務場面に おける正確性について，生理的变化の分析を含めた 今後の検討が必要である.

また本研究の結果は, 質問表単位で見た感度・特 異度であり, 被検査者がその質問内容と一致する記 憶を有する場合と有さない場合に，それぞれ正しく 判断される程度を示している.したがって，今回示 された CIT の感度・特異度などの数值は, 犯人で ある被検査者が犯人と判断される確率, あるいは無 実の被検査者が無実と判断される確率を示すもので はない。例えば $95 \%$ という特異度は，無実の被検査 者の 5\%が誤って犯人と判断されることを意味しな い.今回の実験とは異なり, 実務検査では一般に質 問表を 4-7 表程度実施する ${ }^{3)}$. 仮に事件内容を全く 知らない無実の被検査者を対象に 4 質問表を実施し た場合，全ての質問表について記憶を有すると䛊っ て判断される確率は，単純計算では 5\%（100-特異 
度）の 4 乗 $(0.000625 \%)$ となる。つまり，このよ うな被検査者は，一部の質問表について記憶を有す ると判断されることがあったとしても，複数の質問 表にそれが生じる可能性は低くなる，実際場面で捜 查官・裁判官などが検査結果を捜査上・司法上の判 断に関連づけて評価するには，実施した質問表の数 や内容なども考慮する必要がある。 また，先行知見 と比較する際にも, 特に海外の CIT 研究では, 記 憶の有無々被検查者が犯人か無実かの概念的区別が 明確ではないので注意が必要である10).

さらに，本研究の手続きは裁決質問法に分類され るため，今回示された正確性は裁決質問法のもので ある. 探索質問法では，事前に定めた “指輪”の上 うな特定の項目（裁決項目）ではなく，質問表内の 何れかの項目に并別的な生理的变化が生じれば，そ の項目を事件内容として知っていると推定する. 単 純に考えると，探索質問法において，裁決質問法と 同じ基準でデータを評価した場合，本当は記憶を有 さないケースで誤って記憶を有すると結論する確率 は，質問項目が 5 項目であれば 5 倍になると考えら れる11)。しかし，これは例えば本研究に打ける Lykken Scoring の基準值のような生理的変化の評 価基準が，裁決質問法と探索質問法で異ならないと 仮定した場合であり，実際にこのような結果が得ら れるとは限らない。探索質問法に抢ける正確性につ いては，今後の検討が必要である.

本研究では，専門的知識を有する実験者による判 定は， Lykken Scoringによる客観的判定をやや上 回る判定成績を示した. Lykken Scoring は，海外 のCIT 研究では良く知られた客観的スコアリング 手続きであるが，日本の CIT 研究での利用例はほ とんど見られない。判定結果の特異度が $90 \%$ 以上と なるように基準值を設定した場合でも，80\%以上の 感度が得られたことは，本手法が一定の有用性を持 つことを示唆する。しかし，判定法の詳細な論考は 本研究の目的を越える. この手法の妥当性・有用性 の評価には，少なくとも異なるデータセットを用い た交差妥当化や，探索質問法への拡張などの検討が 必要である。また，実験者による判断に比べて不明 判定事例数が相対的に多かった点や，尺度水準を順 序尺度に直すことの是非 ${ }^{14)}$, 複数指標の結合手続き
なども慎重に吟味しなければならない。

\section{謝 辞}

本研究の実施にあたっては, 以下の機関の方々に 多大なるご協力を頂きました：警察庁刑事局犯罪鑑 識官, 北海道警察本部刑事部科学捜查研究所, 青森 県警察本部刑事部科学捜査研究所, 秋田県警察本部 刑事部科学捜查研究所, 警視庁科学捜査研究所, 茨 城県警察本部刑事部科学捜査研究所, 栃木県警察本 部刑事部科学捜査研究所, 埼玉県警察本部刑事部科 学捜査研究所, 千葉県警察本部刑事部科学捜査研究 所, 神奈川県警察本部科学捜査研究所, 新潟県警察 本部刑事部科学捜査研究所, 岐阜県警察本部刑事部 科学捜査研究所, 愛知県警察本部刑事部科学捜査研 究所, 兵庫県警察本部刑事部科学捜査研究所, 鳥取 県警察本部刑事部科学捜査研究所, 島根県警察本部 刑事部科学捜査研究所, 岡山県警察本部刑事部科学 捜査研究所, 広島県警察本部刑事部科学捜査研究 所, 香川県警察本部刑事部科学捜査研究所, 福岡県 警察本部刑事部科学捜査研究所, 佐賀県警察本部刑 事部科学捜査研究所, 宮崎県警察本部刑事部科学捜 查研究所, 鹿児島県警察本部刑事部科学捜査研究 所, 沖縄県警察本部刑事部科学捜査研究所. 謹んで 感謝の意を表します。

\section{引用文献}

1) Lykken, D. T.: The GSR in the detection of guilt. J. Appl. Psychol., 43, 385-388 (1959).

2) Lykken, D. T.: The validity of the guilty knowledge technique: The effects of faking. $J$. Appl. Psychol., 44, 258-262 (1960).

3）小林孝寛，吉本か抢り，藤原修治：実務ポリ グラフ検査の現状. 生理心理学と精神生理学, 27, 5-15 (2009).

4）㱜田圭男：ポリグラフ検査の有効性. 科学警 察研究所報告法科学編, 24, 230-235 (1971).

5) Elaad, E.: Detection of guilty knowledge in real-life criminal investigations. J. Appl. Psychol., 75, 521-529 (1990).

6) Elaad, E., Ginton, A., and Jungman, N.: Detection measures in real-life criminal guilty 
knowledge tests. J. Appl. Psychol., 77, 757-767 (1992).

7) Ben-Shakhar, G., and Elaad, E.: The validity of psychophysiological detection of information with the Guilty Knowledge Test: A meta-analytic review. J. Appl. Psychol., 88, 131-151 (2003).

8) Ben-Shakhar, G., and Furedy, J. J.: Theories and applications in the detection of deception: $A$ psychophysiological and international perspective. New York: Springer-Verlag (1990).

9) MacLaren, V. V.: A quantitative review of the guilty knowledge test. J. Appl. Psychol., 86, 674683 (2001).

10）小川時洋, 松田いづみ：日本における隠匿情 報検査: 海外との比較. 科学警察研究所報告法 科学編, (印刷中).

11）横井幸久, 岡崎伊寿, 桐生正幸, 倉持 隆, 大浜強志：実務事例に抢ける Guilty Knowledge Test $の$ 妥当性. 犯罪心理学研究, 39, 15-27 (2001).

12）廣田昭久, 澤田幸展, 田中豪一, 長野祐一 郎, 松田いづみ, 高澤則美 : 新たな精神生理学 的虚偽検出の指標: 規準化脈波容積の適用可能 性生理心理学々精神生理学, 21, 217-230 (2003).

13) Furedy, J. J.: The concealed information test as an instrument of applied differential psychophysiology: Methodological considerations. Appl. Psychophysiol. Biofeedback, 34, 149-160 (2009).
14) Meijer. E., Verschuere, B., and Ben-Shakhar, G.: Practical guidelines for developing a CIT. In B. Verschuere, G. Ben-Shakhar and E. Meijer (Eds.), Memory Detection: Theory and Application of the Concealed Information Test, pp. 293302, Cambridge University Press (2011).

15）足立浩平，鈴木昭宏：生理指標間の虚偽検出 精度の比較. 応用心理学研究, 16, 33-43, (1991).

16) Adachi, K.: Statistical classification procedures for polygraph tests of guilty knowledge. Behaviometrika, 22, 49-66 (1995).

17) Cohen, J.: Statistical power analysis for the behavioral sciences $\left(2^{\text {nd }}\right.$ ed). Hillsdale, NJ: Lawrence Erlbaum (1988).

18) Simel, D. L., Feussner, J. R., Delong, E. R., and Matchar, D. B.: Intermediate, indeterminate, and uninterpretable diagnostic test results. Med. Decis. Mak., 7, 107-114 (1987).

19) Carmel, D., Dayan, E., Naveh, A., Raveh, O., and Ben-Shakhar, G.: Estimating the Validity of the Guilty Knowledge Test From Simulated Experiments: The External Validity of Mock Crime Studies. J. Exp. Psychol.: Appl., 9, 261-269 (2003).

20）高澤則美 : 特集に寄せて：ポリグラフ検査一 日本に打碒査実務と研究の動向一. 生理心 理学々精神生理学, 27, 1-4 (2009). 